\title{
論文
}

\section{Plastic Flow of Amorphous Poly(vinyl chloride) in the Glassy State}

\author{
by \\ Yukuo NANZAI \\ Faculty of Engineering, Osaka City University, Sumiyoshi-ku, Osaka 558
}

Tensile flow of amorphous poly(vinyl chloride) in the glassy state was examined. The behavior at the lower yield point was compared with the behavior at the upper yield point that had been considered to be a state of pure plastic flow. As was found previously for other polymers, the upper yield point was influenced significantly by the glass transition, while the lower yield point was not. The upper and lower yield points were examined in terms of phenomenologies by Roetling, Bauwens et al. and Brady et al. and of molecular theories by Robertson and by Argon for plastic flow of glassy polymers. No satisfactory agreements of the theories were seen with our results for the upper yield point. However, Robertson's structural temperature theory showed a fairly good agreement with our results obtained at the lower yield point as well as with those for other amorphous polymers reported elsewhere.

\section{非晶ポリ塩化ビニルのガラス状態における塑性流れ ${ }^{* 1}$}

\author{
南斎 征 夫*2 \\ （原稿受理：1982年6月28日）
}

\section{1. 緒}

\section{言}

線状無定形高分子をガラス状態で単軸定速延伸すると, 真の応 力ーひずみ曲線は, 降伏点と呼ばれている応力極大点（上降伏点） を示す.さらに延伸すると応力降下を経て, 応力極小(下降伏点) の状態を保った後, 応力は再び徐々に増加し始める. これら上下 の降伏点は塑性流れの状態とみることができ, とりわけ上降伏点 については数多くの現象論的扣よび理論的検討が加えられてき た ${ }^{1) ~ 3)}$. しかし, 数種の高分子材料による筆者の検証によれば4),5), 上降伏点に括ける実験データは塑性流れ理論との適合性が必ずし も良くはない，これ対して，下降伏点に括ける実験データは， 塑性流れの分子論と多くの場合 ${ }^{4), 5)}$ 上く一致する。 このことは, 上降伏点での挙動を純粋な塑性流れの状態とする従前の説明が成 立し難いことを示すものである．

*1 本報を “固体高分子の塑性流九関する研究” 第 3 報とする。

$* 2$ 大阪市立大学工学部 $\overline{\mathrm{T}} 558$ 大阪市住吉区杉本 $3-3-138$
本研究では, 上記の検証結果をさらに確かめるため, 非晶ポリ 塩化ビニル (PVC) を試料として, ガラス領域からガラス転移領 域にわたり，上下の降伏点に関して詳細なデータを求めた．以下 でその結果を示すとともに, 上下の降伏点について塑性流れの理 論を検証した。

\section{2. 実 験}

厚さ $2 \mathrm{~mm}$ の市販の非晶ポリ塩化ビニル板（素材の PVC は鐘 淵化学製) より幅 $5 \mathrm{~mm}$, 長さ $50 \mathrm{~mm}$ の平行部を持つ試験片を切 り出した。加工後, 試験片を $96^{\circ} \mathrm{Cで} 2$ 時間保持した後徐冷し, 熱 処理した。な抏，熱処理後偏光顕微鏡観察により試料が非晶質で あることを確認した。この試験片を用いてインストロン型の材料 試験機により，単軸延伸試験怙よび応力緩和試験を行った。

\section{3. 実験結果および考察}




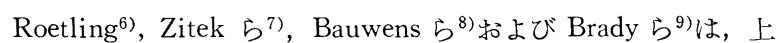
降伏点について得た塑性流れの活性化エネルギーの值に基づいて， 流れには副分散の分子運動が関係すると説明した。

一方, これらの現象諭に対して, Robertson ${ }^{2)}$ と Argon $^{3}$ は, 流 れが主鎖のミクロブラウン運動によるとする理諭を提案した。 Robertson は, ガラス状態の分子鎖のコンフォメーションはせん 断応力によって，メルトの分子鎖のコンフォメーションへと活性 化され，よってガラスの流れが起こると考觉た. Robertson によ れば, ガラス状高分子の流れのせん断ひずみ速度 $\dot{\gamma}$ とせん断応力 $\tau$ の関係は,

$$
\dot{\gamma}=\frac{\tau}{\eta_{t h}}
$$

で与兄られ，粘度 $\eta_{t h}$ は

$$
\eta_{t h}=A \exp \left(\frac{\Delta H_{\eta}}{R T}\right)
$$

である。式(2)の活性化エネルギー $\Delta H_{\eta}$ は，構造温度 $\theta_{1}{ }^{10)}$ に捺け る粘弾性的緩和時間の見掛けの活性化エネルギー $\Delta H_{a}$ と注涪等 しく, WLF 式により ${ }^{11)}$

$$
\Delta H_{\eta} \fallingdotseq \Delta H_{a}=\frac{2.303 R C_{1}{ }^{g} C_{2}{ }^{g} \theta_{1}{ }^{2}}{\left(\theta_{1}-T_{g}+C_{2}{ }^{g}\right)^{2}}
$$

で与えられる。ここに, 構造温度 $\theta_{1}$ は次式で表される ${ }^{12)}$.

$$
\begin{aligned}
\theta_{1}= & \Delta E / k \ln \left\{\frac { 2 v _ { e } \tau } { k T } \left[\ln \frac{1+\exp \left\{-\left(\Delta E-v_{e} \tau+p \Omega\right) / k T\right\}}{1+\exp \left(-\Delta E / k \theta_{g}\right)}\right.\right. \\
& \left.\left.+\left(\frac{v_{e} \tau}{k T}+\frac{p \Omega}{k T}+\frac{\Delta E}{k T}-\frac{\Delta E}{k \theta_{g}}\right) \frac{\exp \left(-\Delta E / k \theta_{g}\right)}{1+\exp \left(-\Delta E / k \theta_{g}\right)}\right]^{-1}-1\right\}
\end{aligned}
$$

ただし， $\Delta E$ はセグメントの活性化の前後のポテンシャル・エネ ルギー差, $v_{e}$ は 1 個のセグメントの容積, $\theta_{g}$ は周囲温度 $T$ に対 してコンフォメーションが平衡する温度, $p$ は静水圧, $\Omega$ は Duckett $ら^{12)}$ が提案した静水圧活性化体積である.

Argon は, Robertson 理論と同様に, 応力によるコンフォメー

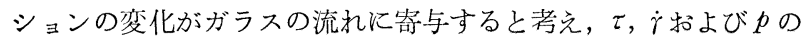
関係を次式で与えた。

$$
\dot{\gamma}=\dot{\gamma}_{0} \exp \left(-\frac{\Delta G_{f}^{*}}{k T}\right)
$$

ただし，

$\Delta G_{f}^{*}=\frac{3 \pi \mu \omega^{2} a^{3}}{16(1-\nu)}\left[1-8.5(1-\nu)^{5 / 6}\left(\frac{\tau}{\mu}\right)^{5 / 6}\right]+0.15 \omega^{2} a^{3}\left(1-\frac{0.6}{\omega}\right)^{2} p$

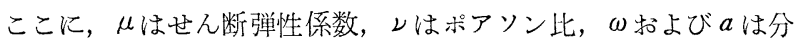
子定数である.

本報では, PVC の上降伏点特よび下降伏点に扣ける応力, ひ ずみ速度拉よび温度の関係を明らかにし，ガラス状高分子の塑性 流れの分子論との適合性を検討した。

\section{$3 \cdot 2 \Delta \boldsymbol{H}_{a}$ およびガラス転移温度 $\boldsymbol{T}_{g}$}

Robertson 理論の検証に必要な $\Delta H_{a}$ と温度の関係を Fig. 1 に示した。図の実線は供試々料の緩和縦弾性率 $E(t)$ から求めた 值であり, 一方破線は $E(t)$ の高温側データより決定されたWLF 係数 $C_{1}{ }^{g}=14.7, C_{2}{ }^{g}=32.6$ を使って，WLF のエネルギー式によ り計算した值である. 実線と破線はガラス転移点のごく近傍を除 きほ汸一致する。な括， $\Delta H_{a}$ の実測值がピークとなる温度を試料 のガラス転移温度 $T_{g}$ とみなし， $T_{g}=63^{\circ} \mathrm{C}$ とた。

\section{$3 \cdot 3$ 上降状点における塑性流れ}

上降伏点に和ける真の引張応力扣よび引張ひずみ速度を, それ ぞれ $\sigma_{u}$ 拈よび $\dot{\varepsilon}$ とし，Fig. 2 に示すように結果を $\sigma_{u} / T$ と $\log \dot{\varepsilon}$ の関係で表した。 ただし， $\sigma_{u}$ と $\dot{\varepsilon}$ は試料が体積変化を起 こさず，均一に伸びたものとして計算した值である. データに合 わせて引いた実線は, 緩やかに湾曲する曲線となり, また温度が 上年するにつれて曲線間隔が広くなる。この結果は, ガラス転移

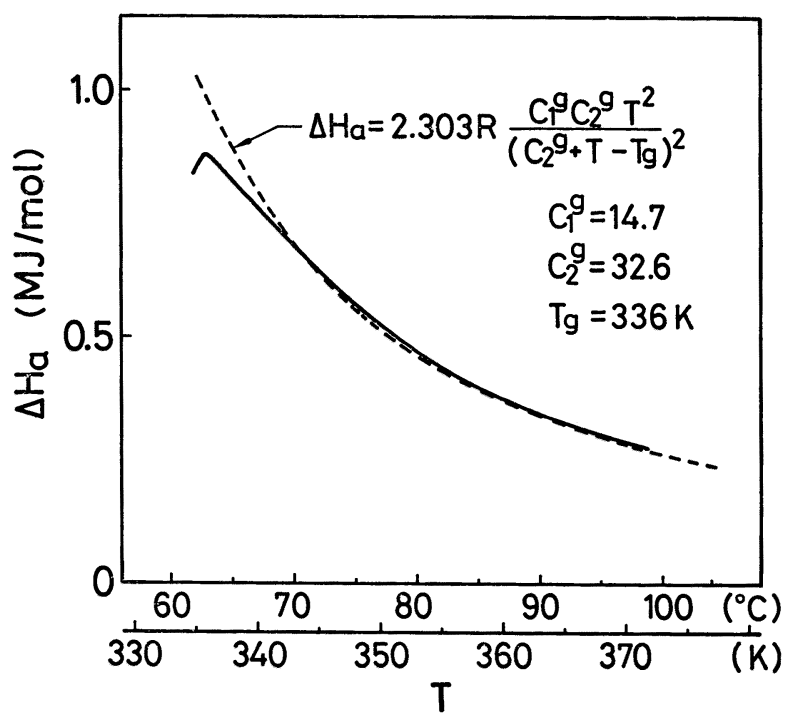

Fig. 1 Temperature dependence of apparent activation energy $\Delta H_{a}$ for viscoelastic relaxation of poly (vinyl chloride).

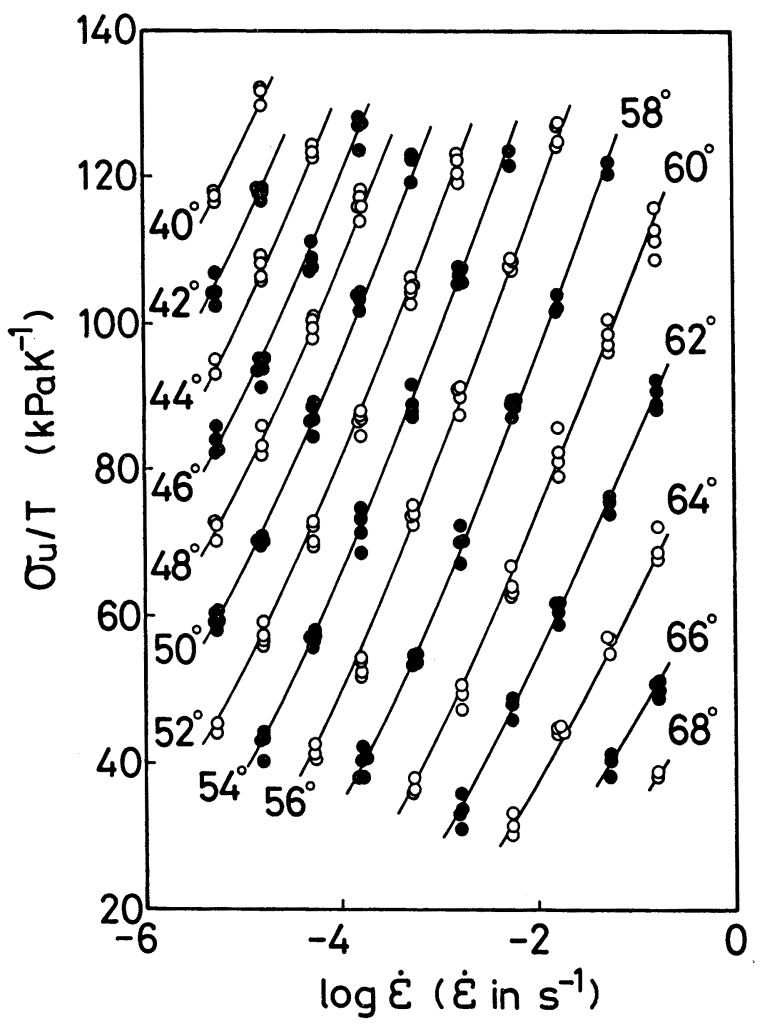

Fig. 2 Ratio of upper yield stress $\sigma_{u}$ to temperature $T$ for PVC plotted against logarithm of strain rate $\dot{\varepsilon}$. 
が $\sigma_{u}$ の挙動に大きく影響していることの現れであり, 既に報告 した他の高分子( ポリメタクリル酸メチル4)，ポリスチレン特よ びポリカーボネート5)（の場合と定性的に同じである，ところで， Roetling $ら^{6) \sim 8)}$ は 1 ない 2 個の Eyring 式莎によって， $\sigma_{u}$ の 挙動を整理できるとしているが，これはデータの傾向が直線的で, かつ転移の影響がない場合に限られる。したがって，Fig. 2 のデ 一タにこの方法を適用することは，既報の場合と同様に困難であ る.

Robertson の指数型の粘度式(2)を, 次に検颉してみよう。ここ では前報5) と同じく，伸長粘度の実験值 $\bar{\eta}_{e x}=\sigma_{u} / \dot{\varepsilon}$ と，式(2), (3), (4)抢よび $\bar{\eta}_{t h}=3 \eta_{t h}$ の関係より求をる伸長粘度の理諭值 $\bar{\eta}_{t h}$ を比 較した。. $\eta_{t h}$ は式(4)，(3)，(2)の順に計算して求め, 式(4)の計算で は $\tau=\sigma_{u} / 2$ 抢よび $p=-\sigma_{u} / 3$ を代入し， $\Delta E$ には Gibbs ら ${ }^{14)}$ による $\Delta E=4.86 \mathrm{~kJ} / \mathrm{mol}$ を, $v_{e}$ には室温での陚料の密度から求 めた $v_{\epsilon}=0.0755 \mathrm{~nm}^{3}$ を用いた。 $\theta_{g}$ は, $T<T_{g}$ の時 $\theta_{g}=T_{g}=336$ $\mathrm{K}, T \geqq T_{g}$ の時 $\theta_{g}=T$ とした ${ }^{2)}$. また，式(2)の定数 $A$ は， $T=T_{g}$ に拈いて $\left.\eta_{t h}=\eta_{g}=10^{12} \mathrm{P}_{\mathrm{a}} \mathrm{s}^{15}\right)$ となるように定めた。. 結果をFig. 3 (a) 亿示す。図の上側の曲線群は実験值 $\bar{\eta}_{e x}$ であり, 下侧の曲線群 は式(4)に㧊いて $\Omega=0$ ( $p$ の影響を考虑しない) として求めた計算 值 $\bar{\eta}_{t h}$ である. $\log \bar{\eta}_{t h}$ の目盛が $\log \bar{\eta}_{e x}$ の目盛の10倍になってい ることから明らかなように， $\bar{\eta}_{t h}$ は $\bar{\eta}_{e x}$ に比べ高ひずみ速度側で 急激に小さくなる。京た， $\Omega \neq 0$ として静水压の影響を考慮した 場合， $\bar{\eta}_{t h}$ はさらに低い值として求まる。したがって，既報と同 様に， $\bar{\eta}_{t h}$ と $\bar{\eta}_{e x}$ とが一致する場合は少ない。

ところで, Robertsonが用いた式(1)と(2)は, Eyring の粘性式 ${ }^{13)}$

$$
\dot{\gamma}=C_{1} T \exp \left(-\frac{\Delta H_{\eta}}{R T}\right) \sinh \left(\frac{\tau v_{a}}{2 k T}\right)
$$

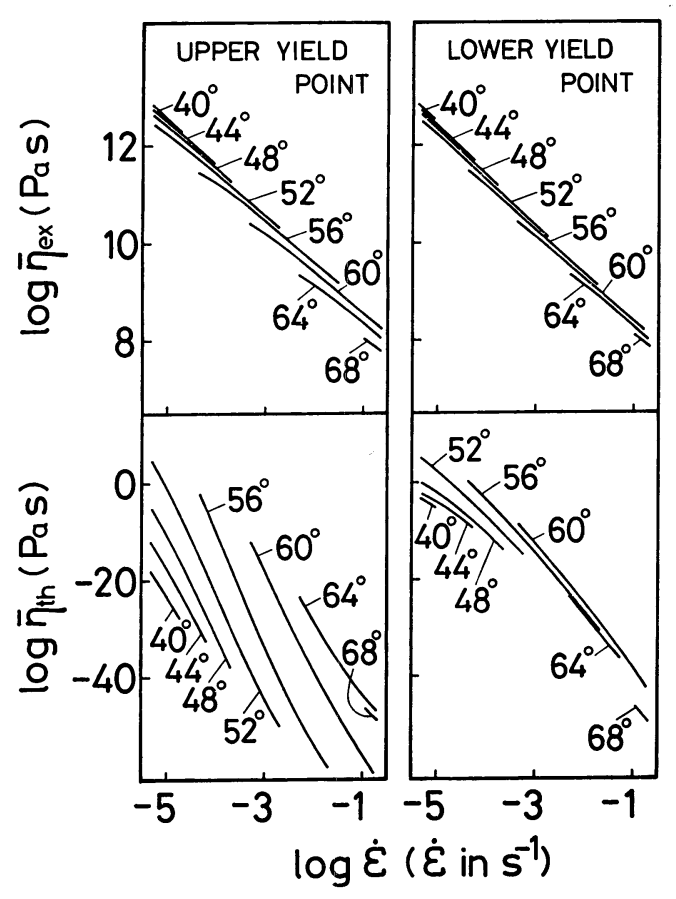

(a)

(b)

Fig. 3 Comparison between logarithm of experimental and theoretical tensile viscosities, $\bar{\eta}_{e x}$ and $\bar{\eta}_{t h}$, for PVC at upper (a) and lower yield point (b). $\bar{\eta}_{t h}$ was calculated from eq. (2), (3) and (4).
飞捻いて，せん断応力が微小である $(\tau=0)$ と仮定した場合の式 と同じ形であり, 式(2)の定数を $A=2 k / C_{1} v_{a}$ とすれば, 双方の式 は一致する. しかし, ガラス状の高分子が塑性流れを起こす際に は，一般に破壊応力と比較しうるオーダーの高応力が働いている. そこで $\tau \gg 0$ と仮定して，その場合の式(7)の近似式

$$
\dot{\gamma}=\left(\frac{C_{1} T}{2}\right) \exp \left(-\frac{\Delta H_{\eta}}{R T}\right) \exp \left(\frac{\tau v_{a}}{2 k T}\right)
$$

により, Robertson の構造温度の理論（式(4)）を検証した.

$\tau=\sigma / 2$ 拈よび $\dot{\gamma}=3 \dot{\varepsilon} / 2$ の関係を式(8)に代入し, 两辺の対数を とると,

$$
\frac{\sigma}{T}=\frac{9.21 k}{v_{a}}\left(\log \dot{\varepsilon}-\log \frac{C_{1} T}{3}+\frac{0.434 \Delta H_{\eta}}{R T}\right)
$$

を得る. Robertsonの式(4)を検証するためには, 式(9)が Fig. 2 の 実駼結果飞一致するよう $\Delta H_{\eta}$ を求め, これを式(3)に代入して $\theta_{1}$ を計算し, 一方で式(4)より $\theta_{1}$ の理諭值を計算し, 両者を比較す ればよい.Fig. 2 で同一の $\sigma_{u} / T$ の值て扔いて隣り合う曲線の 傾きが同じであると仮定すれば， $\Delta H_{\eta}$ は横軸方向の曲線間隔から 近似的に求まる。 $\Delta H_{\eta}$ の結果は, 後汇述べる現象諭の検証に必要 なので, 温度を横軸にとり Fig. 4 にまとめておいた。こうして 求めた $\Delta H_{\eta}$ を式(3)代入し得られる篭造温度の実験值を $\theta_{1}$ *で 表すことにし, 式(4)から計算される $\theta_{1}$ と比較した。 ただし, 式 (4)の係数には, 式(2)の検証で使用したのと同じ值を使った. 結果 をFig. 5 に示す.横軸は便宜的に $\log \dot{\varepsilon}$ とし， $\theta_{1}$ * は白丸で, また $\theta_{1}$ は $\Omega=0,0.045$ および $0.075 \mathrm{~nm}^{3}$ とした場合について， それぞれ一点鎖線, 実線抢よび破線で示した。低温側では $\log \dot{\varepsilon}$ の增加に対し, $\theta_{1}$ と $\theta_{1}$ * は同様飞増加するが, $T_{g}\left(63^{\circ} \mathrm{C}\right)$ の近傍 では $\log \dot{\varepsilon}$ の增加に対し, $\theta_{1}$ * は逆に減少し, 広い範囲での一致 は得られない。この結畟は前報5でのポリカーボネートの結果と 定性的に同じである.

さて, Argon 理論の検証では, 式(5)と(8)が同じ形であるから, 理諭值 $\Delta G_{f}$ *とそれに対応する実験值 $\Delta H_{\eta}-\left(\tau v_{a} / 2\right)$ を比較した. せん断活性化体積 $v_{a}$ は, 式(9)飞見るよ5に Fig. 2 の曲線の傾き $\partial(\sigma / T) / \partial(\log \dot{\varepsilon})$ から求まり, 寸でに求めた $\Delta H_{\eta}$ とから, 実験 值 $\Delta H_{\eta}-\left(\tau v_{a} / 2\right)$ の值が得られる. 一方, 式(6)飞よる $\Delta G_{f} *$ の計

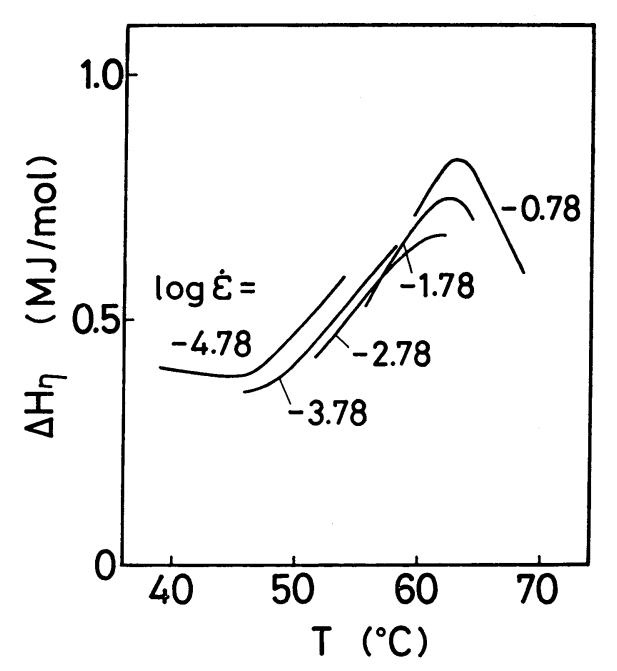

Fig. 4 Apparent activation energy $\Delta H_{\eta}$ for plastic flow at upper yield point plotted against temperature. 


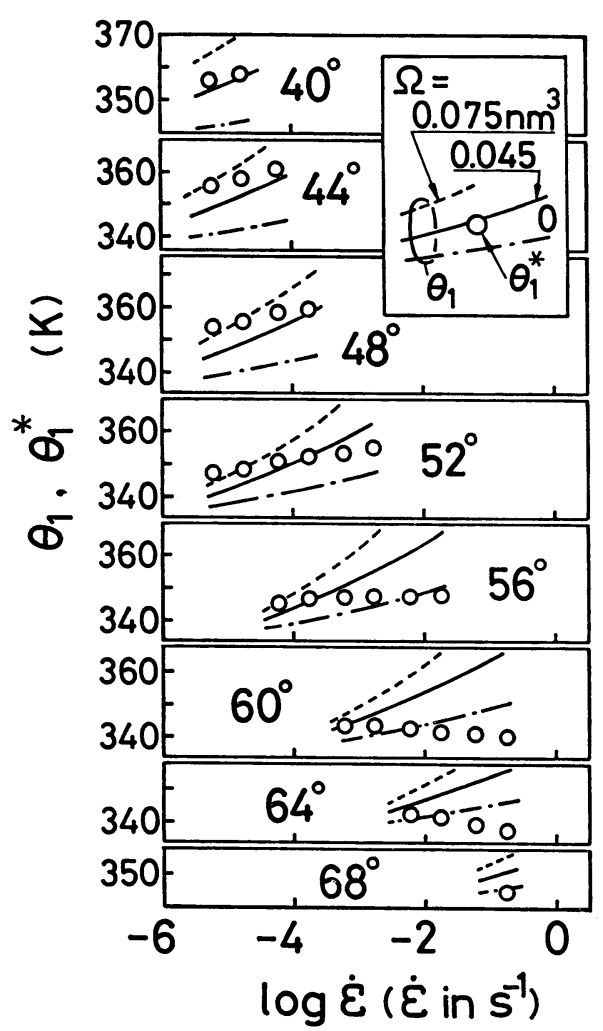

Fig. 5 Comparison between Robertson's theoretical structural temperature $\theta_{1}$ and the experimental value $\theta_{1}{ }^{*}$ at upper yield point for PVC. $\theta_{1}{ }^{*}$ was calculated by using eq. (3). In the calculation, $\Delta H_{\eta}$ in Fig. 4 was used.

算では, $\mu=E / 3$ と仮定し各温度での縦弾性係数 $E$ として $t=0.1 \mathrm{~s}$ に挌ける $E(t)$ の值を用い, セグメントの回転角 $\omega$ は 1.40 , 円筒 状と仮定した分子鎖の半径 $a$ は $0.92 \mathrm{~nm}$ とし， 結果をFig. 6 に示す. 図の左側が実験值, 右側が理論值で, 実 験值は温度の上犁につれて急激に大きくなるのに対し, 計算值は 逆に減少している。

次に現象論を見てみよう。 Bauwens ら ${ }^{16)}$ はVC の延伸試験を $T_{g}$ を含む温度域で行い, $\sigma_{u} / T \sim \log \dot{\varepsilon}$ の図を3つの区域に分け て説明した。 まず， $T<T_{g}$ で高ひずみ速度側の区域 Iでは，デ 一タはガラス転移の影響を受けない平行な直線となり， $\Delta H_{\eta}=$ $70.5 \mathrm{kcal} / \mathrm{mol}(295 \mathrm{~kJ} / \mathrm{mol})$ の Eyring 式で表される. $T \geq T_{g}$ の 区域正では，低ひずみ速度側の曲線部分を無視して重ね合わせを 行えば, 自由体積理論（あるいは WLF 式）によく一致する。 $T$ $<T_{g}$ で低ひずみ速度側の区域 III では，データは本報と同様の曲 線であり，この挙動については説明が困難だと述べている。同様 の結果は, Brady ら 9 によりポリスチレンについて報告されてい る. 彼らは低温側での $\Delta H_{\eta}$ の值が， $\beta$ 分散の粘弾性的緩和時間 の活性化エネルギーに近いことから， $T_{g}$ より低温側での流れに は $\beta$ 分散の分子運動が奇与し $T_{g}$ に打いて主鎖のミクロブラウン 運動に移ると説明した. これらの現象論は, 先に Fig. 4 に示し た $\Delta H_{\eta}$ の変化を比較的よく説明している. しかし, 微小变位粘 弾性の緩和時間の活性化エネルギー $\Delta H_{a}$ は, 時間因子に依存し ないのに刘し， $T_{g}$ 近くでの $\Delta H_{\eta}$ のピークの值はひずみ速度の減 少につれて減少し, 低温側でも $\Delta H_{\eta}$ はひずみ速度に依存してい

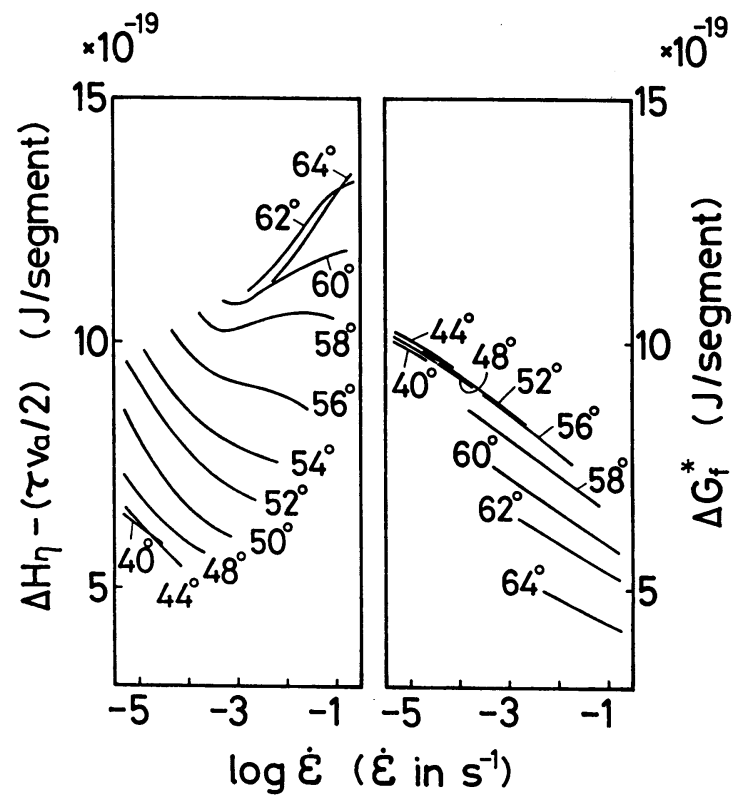

Fig. 6 Comparison between Argon's theoretical activation energy $\Delta G_{f} *$ and the corresponding experimental value $\Delta H_{\eta}-\left(\tau v_{a} / 2\right)$ at upper yield point for PVC.

る。また, PVCの $\beta$ 転移の活性化エネルギーは $14 \mathrm{kcal} / \mathrm{mol}^{8)}$ $(59 \mathrm{~kJ} / \mathrm{mol})$ 程度で, Fig. 4 の低温側の $\Delta H_{\eta}$ よりもはるかに 低い。これらのことは， $\sigma_{u}$ の挙動を微小変位粘弾性の分子運動 のみで説明するのが，必ずしも容易でないことを示している。

以上の結果， $\sigma_{u}$ の挙動はすでに検討した他の高分子の場合と 同様に，ガラス転移の影響を強く受けることが明らかになった。 また，流れの分子論との良い一致は見られなかった，次節では下 降伏点について検討する。

\section{$3 \cdot 4$ 下降伏点における塑性流れ}

下降伏応力 $\sigma_{l}$ および下降伏点に拈けるひずみ速度 が均一に伸びたとみなして計算した。 ただし，降伏の過程で目立 ったくびれを起こした試片のデータは, 実験結果から除外した. $\sigma_{l} / T$ と $\log \dot{\varepsilon}$ の関係を Fig. 7 と示す. 白丸拈よび黑丸が示す 実験值は, 各温度で緩やかな曲線となるので，1ないし 2 個の

Table I. Eyring coefficients at lower yield point.

\begin{tabular}{cccc}
\hline No. $^{\text {a) }}$ & $\begin{array}{c}\Delta H_{\eta} \\
(\mathrm{kJ} / \mathrm{mol})\end{array}$ & $\begin{array}{c}v_{a} \\
\left(\mathrm{~nm}^{3}\right)\end{array}$ & $\log C_{1}$ \\
\hline I & 415 & 5.17 & 58.86 \\
II & 462 & 5.65 & 65.94 \\
III & 486 & 6.20 & 69.43 \\
IV & 514 & 6.87 & 73.49 \\
V & 548 & 7.48 & 78.56 \\
VI & 594 & 8.20 & 85.52 \\
VII & 649 & 9.08 & 93.89 \\
VII & 688 & 9.78 & 99.83 \\
IX & 730 & 10.59 & 106.17 \\
X & 782 & 11.56 & 114.06 \\
\hline
\end{tabular}

a) Roman numerals correspond to those in Fig. 7 . 


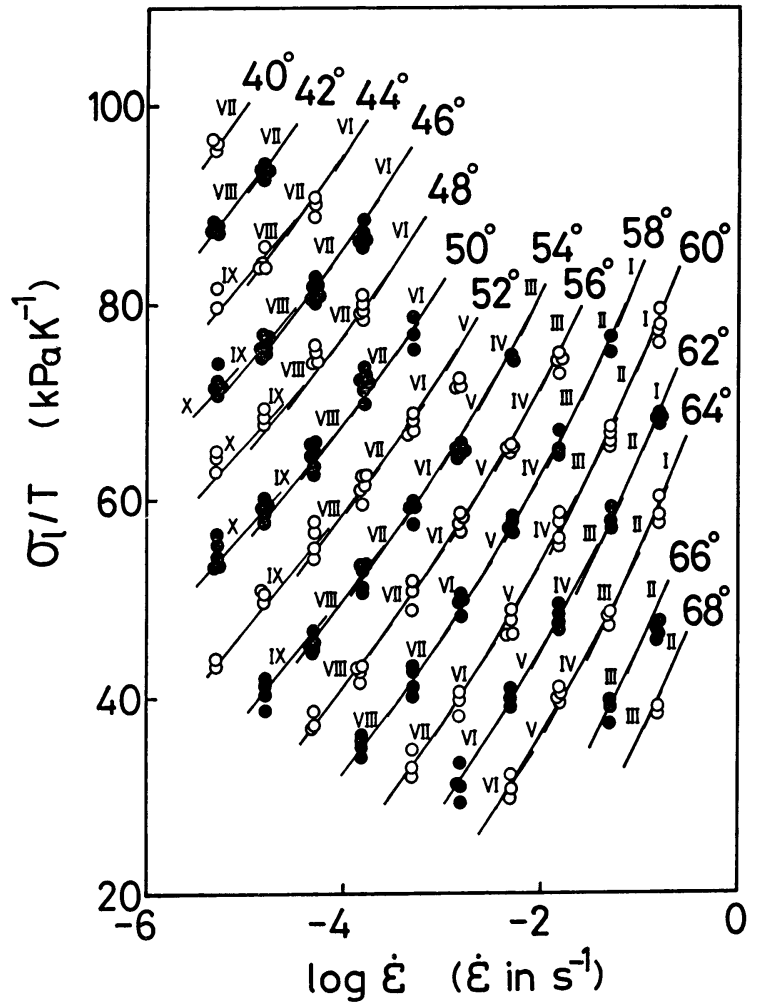

Fig. 7 Ratio of lower yield stress $\sigma_{l}$ to temperature $T$ for PVC plotted against $\log \dot{\varepsilon}$. Short straight lines were used to evaluate the Eyring coefficients, and roman numerals correspond to those in Table I.

Eyring 式によって，この結果を表現することはむずかしい．

Robertson の粘度式(2)について検証した結果を Fig. 3(b) に示 す，上側の曲線群は実験值 $\bar{\eta}_{e x}$ であり, 下側の曲線群は前節と同 じ係数值を使って式(4)，(3)，(2)の順飞計算した理論值 $\bar{\eta}_{t h}$ である. $\bar{\eta}_{t h}$ は $\bar{\eta}_{e x}$ に比べ高ひずみ速度側で急激に減少し, この傾向は静 水圧 $p$ の影響を考虑しても恋わらない。

次に, Eyring 式(9)により $\theta_{1}$ を検討してみる. 既報4),5)で用いた $\sigma_{l} / T \sim \log \dot{\varepsilon}$ の曲線を折れ線により近似する方法は, 本報の Fig. 7 の結果についてもほぼ全域で適用することができた. 図中の各 線分は, Table I にまとめた Eyring 係数により計算したものであ る. Table I の $\Delta H_{\eta}$ から求まる $\theta_{1}{ }^{*}$ と, 式(4)により計算した $\theta_{1}$ をFig. 8 で比較した. ただし, 式(4)の係数には前節と同じ值を 用いた， $\theta_{1}$ を曲線で，一方 $\theta_{1}$ * はとの值を求めた $\Delta H_{\eta}$ の線分が， 実験結果によく適合する $\log \dot{\varepsilon}$ の位置に白丸で示した. $\Omega=0.045$ $\mathrm{nm}^{3}$ として $p$ の影響を考慮すると, 理論值 $\theta_{1}$ は量的にも $\theta_{1} *$ に 一致する場合が多い.

Eyring 係数 $\Delta H_{\eta}, v_{a}$ 打よび $\log C_{1}$ の間の実験的な関数関係 を調べるために， $\Delta H_{\eta}$ を横軸にして $v_{a}$ と $\log C_{1}$ の変化をプロ ットし, Fig. 9亿示した. 図中の二直線は, それぞれ次の式で表 される。

$$
\begin{aligned}
& v_{a}=0.01764 \Delta H_{\eta}-2.29 \\
& \log C_{1}=0.1505 \Delta H_{\eta}-3.72
\end{aligned}
$$

$v_{a}$ 扣よび $\log C_{1}$ は，それぞれ $\Delta H_{\eta}$ とよい相関（相関係数 $r$ は

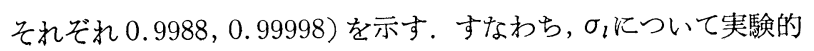

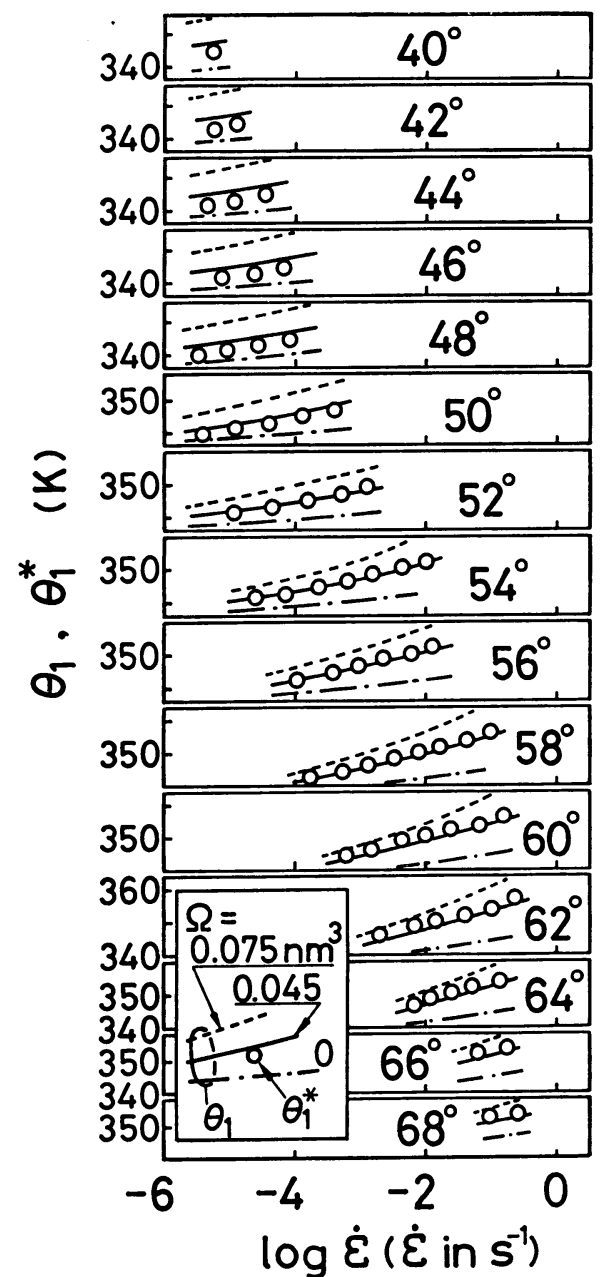

Fig. 8 Comparison between $\theta_{1}$ and $\theta_{1}{ }^{*}$ at lower yield point for PVC. $\theta_{1} *$ was calculated by using eq. (3). In the calculation, $\Delta H_{\eta}$ in Table I was used.

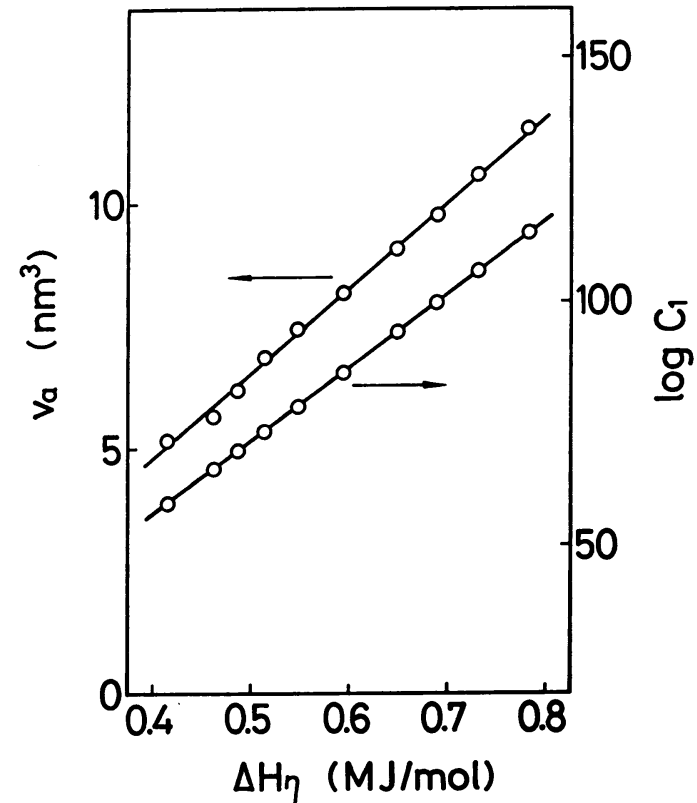

Fig. 9 Linear relations among the experimental Eyring coefficients obtained at lower yield point, $\Delta H_{\eta}$, $v_{a}$ and $\log C_{1}$. 


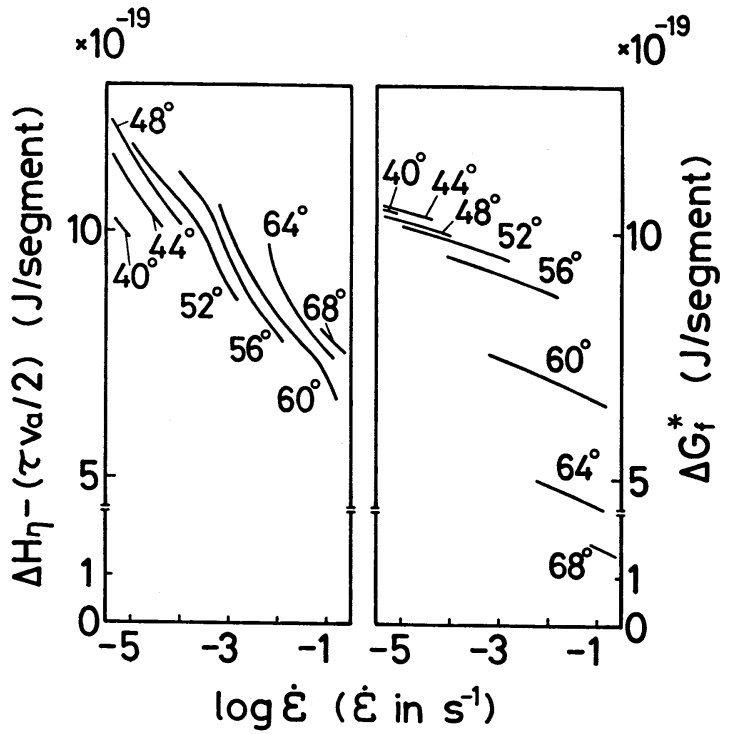

Fig. 10 Comparison between $\Delta G_{f} *$ and $\Delta H_{\eta}-\left(\tau v_{a} / 2\right)$ at lower yield point for PVC.

に求まる Eyring 係数の間には, 㴗湾一次の関係が存在している。 同様の結果は, ポリメタクリル酸メチルなどの高分子についても 認められている ${ }^{4), 5)}$. 係数間にこのような直線関係が存在するこ とは，未だ匡とんど知られていないようであり，この件について の考察は今後の重要な課題の一つであると考えている.

続いて， $\sigma_{l}$ について Argon の理論值 $\Delta G_{f} *$ と，その実験值 $\Delta H_{\eta}-\left(\tau v_{a} / 2\right)$ を比較した. 結果を Fig. 10 亿示す. ただし, 式 (6)の係数には前節と同じ值を用いた。低温側では両者の值は量的 に近いが, 理論值の $\log \dot{\varepsilon}$ に対する変化が比較的なだらかなのに 対し, 実験值の変化は急である。 また, $\Delta G_{f} *$ は実験值に比べ $T_{g}$ 近くで急激に小さくなる。

最後に，現象諭について述べて扔こう。原から求まる $\Delta H_{\eta}$ は, Table I と Fig. 7 に見られるように，ひずみ速度が大きくなるほ ぞ減少し, 明らかにひずみ速度依存性を示す。また， $\sigma_{l}$ の場合に は $\sigma_{u}$ に見られたガラス転移の影響が認められない。これらの結 果は, 微小変位粘弾性のデータと対応するところがないので, 下 降伏点での塑性流れを微小変位での分子運動と関連つけて説明す ることは困難である。

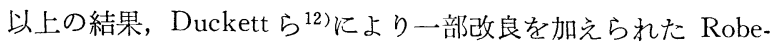

rtson の满造温度の理諭は, PVC の下降伏点の実験結果とよく適 令することが明らかになった。すでに報告したように，ポリメタ クリル酸メチル4)，ポリスチレン拉よびポリカーボネート5)の場 合にも同様の結果が得られて招り, 線状無定形高分子の下降伏点 には, 構造温度の理諭がよく適合することが, さらに確認された ことになる。

（本報の一部は，1980年10月22日第28回レオロジー討論会に打 いて講演した.）

\section{文}

献

1) Ward, I.M., J. Mater. Sci., 6, 1397 (1971).

2) Robertson, R.E., J. Chem. Phys., 44, 3950 (1966).

3) Argon, A.S., Phil. Mag., 28, 839 (1973).

4）南紊征夫, 高分子諭文集，38，399 (1981).

5）南斎征夫, 日本レオロジー学会誌， 10，61 (1982).

6) Roetling, J.A., 6, 311 (1965).

7) Zitek, P. and J. Zelinger, J. Appl. Polym. Sci., 14, 1243 (1970).

8) Bauwens-Crowet, C., J.C. Bauwens and G. Homès, J. Polym. Sci., A-2, 7, 735 (1969).

9) Brady, T.E. and G.S.Y. Yeh, J. Macromol. Sci.-Phys., B9(4), 695 (1974).

10) Kambour, R.P. and R.E. Robertson, "Polymer Science", 1, 791 (1972), A.D. Jenkins, Ed., North-Holland, Amsterdam.

11) Ferry, J.D., "Viscoelastic Properties of Polymer", Chapter 11 (1961), John Wiley \& Sons, New York.

12) Duckett, R.A., S. Rabinowitz, and I.M. Ward, $J$. Mater. Sci., 5, 909 (1970).

13) Glasstone, S., K.J. Laidler and H. Eyring, "The Theory of Rate Process", p. 480 (1941), McGraw-Hill, New York.

14) Gibbs, J.H. and E.A. DiMarzio, J. Chem. Phys., 28, 373 (1958).

15) Miller, A.A., J. Polym. Sci., A, 2, 1095 (1964).

16) Bauwens, J.C., C. Bauwens-Crowet and G. Homès, J. Polym. Sci., A-2, 7, 1745 (1969). 